\title{
Exploring Students' Religiosity and Halal Lifestyle
}

\author{
Nur Indah Riwajanti*, Anik Kusmintarti, Fadloli El Shinta Mangku Alam \\ Accounting Department \\ State Polytechnic Malang \\ Malang, Indonesia \\ *nur.indah@polinema.ac.id
}

\begin{abstract}
This research aims to explore students religiosity and halal lifestyle. The data was collected through Focus Group Discussion with 18 students from four institutions in Malang area, those are State Polytechnics Malang (Polinema), Brawijaya University (UB), State University Malang (UM) and State Islamic University Malang (UIN). Then, the data was analyzed based on data reduction analysis. The findings show that the informants admitted to have high level of religiosity in terms of their faith. However, they didn't perform fully in accordance with their faith since they didn't practiced all forms of wordships and the Islamic values due to some reasons such as environmental influence during college, loose of control parents, and high amount of work and assignment. Related to halal lifestyle, the informants revealed that they have sufficient knowledge about halal aspects of food and beverages; but this knowledge is limited when it is related to medicine and financial services. To increase halal awareness among students, it is suggested that related institutions should improve the education process towards young generation through ways that suit their lifestyle which has high reliance on social media.
\end{abstract}

Keywords: students, religiosity, halal lifestyles

\section{INTRODUCTION}

The concept of halal in Islam emphasizes the importance of Muslims to consume only halal products such as food, drinks, medicines, cosmetics etc. "Halal" is defined as things that are allowed to be used/consumed by a Muslim. The opposite of the word halal is "haram" which means forbidden. The concept of halal does not only concern the product consumed, but also involves service, including financial services that must be free from usury, halal tourism services etc. [1]. The development of halal lifestyles (halal lifestyle) emerged in recent years driven by the growth of public awareness to apply the teachings of Islam in all aspects of life. This encourages the rapid growth of the halal market on a global scale in various continents, including Asia [1].

In Indonesia, to ensure that Muslims could consume halal products, Law Number 33 in 2014 is approved by the Indonesian Ulema Council (MUI) through the LPPOM-MUI (Food, Medicine and Cosmetics Research Institute) as an institution that provides halal certification. Until now, the number of products that have received halal certification from LPPOM-MUI from 2012 to October 2017 has reached 259,984 products from 6,055 . Increasing the number of products that received halal certification in response to the increasing demand and concern for the public to consume halal products. It also directly shows the role of religion in people's lives.
Religion influences one's attitude, values and behavior [2], which in turn creates a halal lifestyle.

Instilling halal lifestyle habits should begin at an early age. The closest environment, that is parents and schools, have a strategic role to instill the importance of consuming hala products. To see whether the halal life campaign has been implemented or not among the younger generation, especially students, it is important to know how the halal lifestyle is understood by students. Teenagers are young people who still have a tendency to try new things that are not all in accordance with the values of Islam and local culture, for example smoking and consuming alcohol. As a result of this negative lifestyle, there are 150 thousand Indonesian teenagers who suffer from HIV [3].

Research on religiosity and a good (halal) lifestyle among students is required, because apparently students are less concerned about consuming halal products. They tend to consider themselves as adults and live far from parental control. Currently, there is no clear information and available empirical evidence, how students care about halal lifestyles. Students are the younger generation who are the nation's successors, it is important for them to have a good level of religiosity and lifestyle. Malang, as a tourist and student city, the number of students is estimated to reach 183 thousand students spread across five large universities namely Brawijaya University, Malang State University, UIN Malik Ibrahim, Muhammadiyah University, and Islamic University Malang [4]. This number does not include students in 26 other tertiary institutions.

Research related to the consumption of halal products has been done by several researchers. Almost all of the previous studies used associative quantitative methods for food, cosmetics and fashion products [5-16] and qualitative from a cultural perspective [14]. However, no research has been found that discusses the students' religiosity and halal lifestyle of by using a qualitative approach to explore deeper into their halal lifestyle. This research aims to explore students' religiosity and halal lifestyle. The results of the research will be useful in mapping the students' halal lifestyle profile and can then be used to formulate a halal life campaign strategy among the younger generation. 


\section{METHODS}

By using a descriptive qualitative research approach, this study aims to explore the concern of Muslim students towards the halal lifestyle. This halal lifestyle is also associated with the level of religiosity, knowledge of halal financial products and services and environmental influences. This study uses qualitative research to be able to describe comprehensively and deeply about the level of religiosity and halal lifestyle of Muslim students of four major higher institutions in Malang, East Java which include State Polytechnic Malang (Polinema), Brawijaya University (UB), Malang State University (UM) and Malang Islamic State University (UIN). Two Focus Group Discussion was held with eighteen Muslim students to explore further the level of religiosity and meaning of the halal lifestyle for them.

\section{RESULTS}

Qualitative data were obtained from two Focus Group Discussion (FGD) meetings with eighteen Muslim students from four higher institutions. Following are the results of the FGD.

\section{A. Religiosity}

The informants generally stated that they had confidence in the existence of the universe creator, namely Allah SWT, with a confidence level of $100 \%$ without doubt. An informant, RR from UIN stated with confidence:

"... surely I trust Allah SWT and the pillars of Islam, because I believe that God gives, creates humans and also its contents. Also, I trust the Prophet Muhammad as a the person who bring Islam".

An informant, FK who is a master's level student from UB also supports by stating that:

"In my opinion 100 percent sure that God does exist and the Prophet Muhammad is also a messenger from God and my belief is pure and there is no coercion and no encouragement from anyone and this is pure from $m e^{\prime \prime}$.

In contrast to informant $\mathrm{H}$ from Malang State Polytechnic, he stated that his beliefs were still lacking and were often shaky when reading books because of differences of opinion from the scholars.

Related to obedience, they have various indicators of obedience assessment, including observing the five-time prayer, reading the holy book of the Koran, carrying out the fasting month of Ramadan, pilgrimage intentions, etc. The informants honestly acknowledged that the majority experienced a decrease in observance in practicing worship after they became university students. FP, the final semester student of UB stated honestly that he had not fully prayed five times a day, but FP kept the 30-day Ramadan fasting completely. Not only FP, one of Malang State Polytechnic students, R, also agreed and explained his experience that:
"From elementary school to junior high school...I was student ... so [my obedience] have increased. But at the beginning of becoming university students, there was a decrease in the level of worship, and I did an evaluation in order to increase worship observance again. Factors that influence the level of worship (prayer and reading the Koran) is the environment, away from family, there is worldly activity. But...I did fasting completely during Ramadan".

The informants also revealed factors that influenced the level of their obedience, one of which was the level of understanding of worship that was carried out. IB, UB student states that:

"I try to always improve my understanding towards worship itself, for example, how to improve the quality of prayer or fasting. What is the correct prayer, how about the correct fasting? The more I come to believe in worship, I realize that my practices in worship are a form of my belief in my religion. Now, I am looking for more "actually, what can we get from Ramadan fasting? What can we get from prayer? ...It turns out that praying is not just asking but it is more to the form of our servitude".

Also, the informant with the initials B, a final year student from Polinema admitted honestly that sometimes the factor influencing his observance in carrying out worship is the demands of the situation. He said openly that there was obedience in him when carrying out worship and always wanted to be close to God when he was in a certain condition for example will conduct a thesis trial.

Lack of self-motivation is acknowledged to be one of the factors affecting the level of religiosity of each person. IB admits that sometimes laziness still haunts him in worshiping Allah SWT. Agreeing with IB, M as a student of UM, also admitted that sometimes he always procrastinated in worship. ES, a Polinema student, also thought the same, she said:

"The level of obedience is ...how often we do it. The problem is usually because it is always delaying prayer and busy on worldly matters. In terms of fasting, for example Ramadan, there is an obligation and desire to complete fasting because it is very mandatory. When reading the Koran sometimes I also see the hadith tempted by the many rewards obtained, and this specifically adds to my sense of enthusiasm for reading the Koran".

The ability to control themselves, support from parents and the environment was also very influential on the observance of students in worship. AM informant from Polinema said that all depends on the trust of each individual. Honestly, informant A from Polinema said that if the factor "went along with friends" resulted in him often delaying his obligatory prayers. In line with the opinions of other informants, students of Polinema, $\mathrm{R}$ also said that he only pray five times a day when supervised and given instructions in advance from parents. 
When observing obedience in refraining from acts that are contrary to Islam, it is found that there are still some young people who cannot control themselves. The RR informant from UIN also revealed the facts:

"I have found that in my environment, everything...from drugs, alcohol and also the problem of pornography. Now, that issue become ordinary for young people. It is acceptable. When it comes to pornography... often watching movies ... adult scenes for "kissing"..."

Another opinion was expressed by informant $\mathrm{R}$ from Polinema which he felt that the worlds that were approaching haram in this millennial period were still difficult to resist. He often found in the case of his peers who looked pious when in front of the general public, but consuming liquor at his home. The informant gave a statement that:

\begin{abstract}
"If there is actions contrary to Islam, this circle or environment also affects, but if for example myself... I sometimes also do things that are contrary, but in my opinion, I'd better to do it now and not to do it again next year, pushed by the circle, inevitably have to follow. But I think it's better for me to be like this now...than later when I'm old or just curious do to this sins. Now, I already know that in the future, if I want to be crushed in the future, I will be able to put the brakes on it, but only for now, like doing these students, are they vulnerable to such things?"
\end{abstract}

Informant $\mathrm{Y}$ from Polinema also agreed with the $\mathrm{R}$ statement. He said that he would try new things as having experience and learning for the sake of his future children. In contrast to the opinions of the informants above, informant $\mathrm{B}$ from Polinema still chose to distance himself from the prohibited activities for fear of the impact in the future and get the karma law from Allah SWT.

Not only pornography, LGBT-related issues are also expected to be common. B from Polinema explained that related to the rise of $\mathrm{LGBT}$ cases:

"This LGBT also happens to be really free. So abroad there is also the name PRIDE, in Instagram also uses the hashtag. So, for example, clicking PRIDE really is "giving an impact in Indonesia to not have to be afraid". Now on YouTube there is also a soft film, because I got a trap. He said the soft film was good and I saw LGBT. So they are brave now, have made their own circuits, have their own social media".

$\mathrm{RR}$, an informant from UIN also revealed the facts:

\section{"...for example of the LGBT problem is actually ...this issue is not new..."}

FP, an informant from UB, also supported RR statement and said that it was an impact of the boarding environment because male and female students were very difficult to interact. However, the majority of informants have been able to distance themselves from acts that are contrary to the Islamic teachings by doing as much as possible positive things such as participating in organizational activities on campus, reducing curiosity about things that are felt to be less useful, joining good friends with good morals but that does not mean distance away. Informant B from Polinema expressed his gratitude because the lecture schedule was very tight on campus, so that he did not have much time to take part in friend invitations on less useful activities. U of UIN honestly also said that he could look after himself when there were friends who were drinking alcohol. The IB informant from UB explicitly also said:

"Personally, I'm against it. Because in Islam it is wrong, but for others... I leave it to them, that's their choice. So I will not judge them, but more for myself it is not allowed".

FK and FP informants from Brawijaya University and AM from Polinema have the same opinion related to the way they avoid something that is forbidden by Islam based on the AlQuran and the knowledge gained and see the impact caused when doing something. FP informants with confidence still use scientific knowledge. He stated that:

"In the social environment I can quite put the brakes on knowledge that might be considered scientific. For example smoking, it can damage your lungs. Even though I am in an environment where my friends are smokers, I am pretty sure I can still refuse, because that is indeed the principle of my life. I no longer want to, I am very sure I don't want to go along, even if I'm not interested. But... for cases like pornography, I admit, it's still affect me. But on the one hand there are positive impacts in my opinion. This is from me personally where a little better than you free sex...".

Related to the deepening and application of the level of religiosity, the majority of informants strengthen their faith by learning from various sources. Those are reading Islamic books, studying or reviewing books, watching video studies on You-Tube and Instagram, following Islamic studies with speakers such as Cak Nun [famous Emha Ainun Nadjib] so there is a transfer of knowledge in fun environment, learn directly with the cleric, and even some of the informants have experienced living in an Islamic boarding school. RR from UIN explained that:

"Actually there are many ways for us to learn. And
the first thing for sure that I emphasize is to study in
such clear custom. Because indeed, if the customs are
not clear, I won't know what their bases are and what
they look like. And secondly, it is discussing with
friends. And discussions with this friend I am more
interested in different groups with me. If I am not
interested in social media, not because it's okay,
maybe yes maybe less interested a little".

Different from other informants, FK actually explores knowledge about Islam by joining the WhatsApp group. SI 
from Polinema also added his opinion that he was also not interested in learning through online video. He revealed that he have a teacher from elementary school up to now, recites not only the Koran but also learned the yellow books and hadiths.

Behavior in getting along in accordance with the Islamic teachings is recognized to have been applied by most informants. An informant explained that he was able to respect differences and advise one another. Informant $\mathrm{R}$ from Polinema said honestly that as much as possible he did not harm others. RA informants from Polinema had also successfully subtly refused a less-than-good invitation. Meanwhile, ES informant from Polinema said that:

"Islamic values teaches us to share with others. Therefore, I apply it by not being stingy, by sharing knowledge with friends, for example, if they have difficulties, I help them by studying together. As much as possible I teach my friend".

\section{B. Knowledge on halal products}

All informants stated that they already knew halal food and beverage products. But the problem is the majority of the informants are still difficult to know the content in the medicine. An informant, FP from Brawijaya University stated that:

"For food and beverages, it is quite easy to recognize the halal aspect, especially if it is sold in retail, such as food and other medicines. But this medicine that I personally feel is rather difficult. Is this medicine halal? But if I personally take it for that long, for example a prescription from a doctor, yes, I will definitely take it"

SI informants from the Department of Mechanical Polinema also supported the opinion of FP. He stated:

"It is easy to recognize halal food and beverage, because there are institutions that are responsible. The medicine are quite difficult to recognised, because we do not know whether they are halal or not to be consumed".

The majority of informants see the halal and illicit content of a product that is from the halal label printed on the product packaging, the FI informant honestly said that sometimes he chose to consume the product in accordance with his belief in the product. Related to knowledge about halal medicine, FK Informant from UB admitted that if he could not judge the content in medicine let alone the composition using chemical terms unknown to many people. $\mathrm{R}$ from Polinema also added that the lack of knowledge related to new terms such as pigs that have kinds of pork, Lart, B2, etc.

Regarding the understanding of financial services, several non-accounting informants stated that they did not understand this. An informant A from Polinema said honestly that only limited to knowing that the usury law is haram. 2 other informants namely SI from UIN and F from Polinema still consider and stay away from usury. F also bluntly said that he did not use conventional banks. The RR informant from UIN also stated that the lack of information related to law and type of bank was the main factor causing the lack of public understanding. He said that:

"I originally used conventional bank.. What I really don't know is what's the difference because I don't really know the issue [about riba].. So there is a friend of mine suggested, than I moved it to one of the Islamic banks".

\section{Environmental impact on halal lifestyle}

Most of the informants said that the environment is very influential on student behavior. ER from UM very confidently explained that:

"That environment really affects us, start from elementary to high school, at home with parents are reminded of prayer, invited to fasting. When we are in college there is no such thing, friends sometimes remind me to obey Islamic rules, and sometimes friends are vary. Now, in my opinion, my environment does not support me for that".

This statement was also supported and added by SI Informants from Polinema who stated that:

"... That really depends on the environment. I think about religion is still awake because at home in my neighborhood there is a study that is ready to teach the Koran. My teacher who teach Koran once said that faith can increase and decrease".

The majority of informants thought that the most influential parties were family, lecturers, friends, and neighbors. Informant R from Polinema stated that the closeness between children and parents is indeed very important for growth, it will look different if parents are very busy so they must leave their baby to the maid. ER, an informant from Malang State University also argued that the influence of lecturers on him. He stated that there were lecturers who were close with students so that discussions and exchanges often occurred outside of class hours which discussed up to the personal lives of students. SI also supports the statement from ER and provides a statement that:

"I place teacher as number two after the family... Because if my teacher says something to remind me when I make mistakes, I always remember what he said. So my teacher is my second parent and I consider him that way, because he teaches me religion and sometimes I know something from him. If I don't know from my parents, I know from my religion teacher.

Different from other informants who strongly agree that there is a strong influence on the environment, the RR informant from UIN actually revealed that:

"Sometimes the environment can influence, sometimes we are people who already have an attitude. So I also have friends and I don't choose friends to hanging out'. 


\section{Students' halal lifestyles}

The informants as a whole answered simultaneously that halal products were selected for consumption. But there are other arguments related to the consumption patterns of food, beverages, and medicine. Informant $\mathrm{H}$ from Polinema acknowledged that prioritizing halal products and seeing the crowd of visitors, because this shows that the food served is very delicious. ES from Polinema also agreed with $\mathrm{H}$. He added that he could see the appearance of the person selling. But FP from UB prefers based on low prices. Regarding the selection of medicines, $\mathrm{H}$ does not care, while it can immediately heal and is needed, so for him it is also not a problem. $\mathrm{H}$ also told that he had experienced an illness where he had to consume Morphine and he still did it for healing. $\mathrm{R}$ from Polinema also agreed with $\mathrm{H}$. He stated that:

"I sometimes consume alcohol indeed, but for food I'm still consider halal food. But sometimes the product has halal certification, but in its composition there are ingredients that are unclean like pork oil. The writing is not pork oil but gelatin, so as consumers, we must understand terms like that. So we not only see from the Halal label, but we must learn and read from the composition. It could be that the sample sent to the MUI is halal, but it is not circulated in the market, it could be uncertain".

In terms of finding information related to halal products, the majority of informants only read the ingredients first, look for related information, buy food that is often consumed, and also get material in lectures so it is safer.

Most of the informants also invited their friends to choose halal products to consume and B from Polinema took the time to explain the benefits when consuming halal products. RR from UIN also honestly states that:

"If you invite, surely ma'am. But as humans we are quite at the limit of reminding like that. Henceforth yes he has his own choice".

Still referring to the halal lifestyle, informants A, F and $\mathrm{R}$ from Polinema agree that they are less concerned in choosing financial services, because for them, bank services are only used when there is a transfer of money from parents. Unlike the 3 informants above, RR from UIN actually paid attention to this and chose a Islamic bank as a place to save. $\mathrm{H}$ from Polinema also did a little consideration in choosing financial services. He stated that:

"Based on the trust and review from people, I chose insurance (AXA, Prudential, AIA, etc.) I was looking for what was more recommended and did not look at conventional or Islamic, which was important for me more to the institution. I also choose which is more profitable".

\section{DISCUSSION}

In general, all informants have good level of religiosity which has been build and developed from their childhood.
However, in term of the implementation of this religiosity, their obedience have been decreased since they become university students. Therefore, their obedience should be improved. Apparently, their level of obedience have been decreased after they live far from family control. Indeed, the influence from close circle, such as friends and family, seem to be very beneficial. It is important to choose friends with whom to share their spare time. Although they convince that they can protect themselves from negative influence, but the power of the close circle [friends] could not be neglected easily. Students' selfcontrol must be encouraged, which they still have spirit to learn Islamic values through various channels, both online and offline.

In their attempt to seek Islamic knowledge, awareness to recognize halal food and beverages seems to appear. They tend to consume only halal food and beverages. Their knowledge related to food and beverages are good, but there is lack of knowledge about halal medicine.

This is caused by the difficulty in understanding the content of the medicine which mostly using the chemist terms. There is a tendency that their awareness of halal medicine is lower compare to awareness of halal food and beverages. Based on the reason that the medicine provided by medical practitioner and their need to cure the sickness, any medicine will be taken without concerning the halal aspect of the related medicine.

The knowledge and awareness of halal aspect even become lower when it relate to financial services. They have limited knowledge about halal (riba free) financial services. Only those students with from economics faculty have higher knowledge related to halal financial services. Some subjects in economics faculty seems to spread knowledge related of Islamic financial products. Unfortunately, students from non-economics faculty do not have such knowledge. This might imply that public education related to Islamic financial products must be improved.

\section{CONCLUSION}

This study revealed that most informants have a good religiosity and sufficient knowledge about halal food and beverage. They have halal concern related to food and beverages, but less concern related to medicine and financial services. Awareness to have halal lifestyles usually limited to food and beverages, which it should also cover halal medicine and financial services. Therefore, students' halal lifestyles should be encouraged through education in various channels including social media and endorsers due to their preference to get close to social media.

\section{REFERENCES}

[1] H. Elasrag, "Halal industry: key challenges and opportunities". 2016.

[2] D.A.Farrag and M. Hassan, The influence of religiosity on Egyptian Muslim youths' attitude towards fashion", Journal of Islamic Marketing, Vol. 6 Issu 1, 2015, pp. 95-108.

[3] Viva, (16 March 2018). Lebih dari 150 ribu remaja Indonesia mengidap HIV. Viva News, accessed from: https://www.viva.co.id/gayahidup/parenting/1017112-lebih-dari-150-ribu-remaja-indonesiamengidap-hiv 
Journal of Islamic Marketing. Vol. 6(1), 2015, 148-163. Doi: https:/doi.org/10.1108/JIMA-09-2013-0068

[4] Kumparan, Puluhan ribu mahasiswa baru siap kepung kota Malang, Friday 13 July 2018.

[5] J. Aertsens, K. Mondelaers, W. Verbeke, J. Buysse and G. Van huylenbroeck, G., "The influence of subjective and objective knowledge on attitude, motivations and consumptions of organic food". Britih Food Journal. V. 113 (11), 2009, pp. 1353-1378.

[6] S.S. Alam, R. Mohd, R., B. Hisham, "Is religiosity an important determinant on Muslim consumer behaviour in Malaysia?", Journal of Islamic Marketing, 2 (1), 83-96., 2011, Pp. 83-96. DOI: 10.1108/17590831111115268

[7] R. Golnaz, B. Zainalabidin, S. Mad Nasir, and F.C. Eddie Chiew, "NonMuslim awareness of halal principles and related food products in Malaysia”. International Food Research Journal. Vol. 17, 2010, pp. 667671.

[8] A. Mukhtar, and M.M. Butt, "Intention to choose Halal products: the role of religiosity", Journal of Islamic Marketing, Vol. 3 Issue: 2, 2012, pp.108-120, https://doi.org/10.1108/17590831211232519

[9] G.P. Mochis and F.S. Ong, "Religiosity and consumer behaviour of older adulsts: a study of subculture influences in Malaysia". Journal of Consumer Behaviour, Vol. 10 No. 1, 2011, pp 8-17.

[10] A.A.. Rahman, E. Asrarhaghigghi, and S.A. Rahan, "Consumers dan halal cosmetics products: knowledge, religiosity, attitude and intention".
[11] A. Rehman, and M.S. Shabbir, "The relationship between religiosity and new product adoption", Journal of Islamic Marketing. Vol. 1 No. 1, 2010, pp 63-69.

[12] S.S. Saabar and S.B. Ibrahim, "The knowledge of halal and advertising influence on young muslim awareness". International proceeding of economics development and Research. Vol 73, 2014, 36-39

[13] F. Salman and K. Siddiqui, "An explanatory study for measuring consumers' awareness and perception towards halal food in Pakistan". Interdisciplinary Journal of Contemporary Research and Business, Vo. 3 No. 2, 2011, pp. 639 halal cosmetics products: knowledge, religiosity, attitude and intention", Journal and Islamic Marketing, Vol. 6, Issue 1, 2015, pp. 148-163

[15] A. Haque, A. Sanwar, F. Yasmin, A. K. Tarofder and M.A. Hosain, "Non-Muslim Customers's perception toward purchasing halal food products in Malaysia", Journal of Islamic marketing, Vol. 6, Issues 1, 2015, pp. 133-147.

[16] C. Bachleda, N. Hamelin and O. Benachour, "Does religiosity impact Moroccan Muslim womens's clothing choise?", Journal of Islamic Marketing, Vol. 5, Issue 2, 2014, pp. 2010-226
[14] A. Abd Rahman, E. Asrarhaghini and S. Ab Rahman, "Consumers and 